\title{
Mechanisms of Innovative Projects Financing in the Culture Industry on the Basis of Public-private Partnership
}

\author{
Nataliya Malshina \\ Faculty of Theory \\ Saratov State Conservatory \\ Saratov, Russia \\ E-mail: malsnataliya@yandex.ru
}

\author{
Anna Firsova \\ Faculty of Economics \\ Saratov State University \\ Saratov, Russia \\ E-mail: a.firsova@rambler.ru
}

\begin{abstract}
Strengthening the role of the culture industry in modern economy makes it relevant to developing scientific and methodological approaches to the organization of its financial support. Among the mechanisms of culture industry financing there are the mechanisms of public-private partnership. The purpose of this study is to identify the prerequisites for the use of public-private partnership and the definition of effective forms of its organization in the field of culture, taking into account the experience of developed countries. The article discusses the main models of financing culture, measures on state support of the development of culture and creativity, and the mechanisms of public-private partnership in the implementation of innovative projects in the field of culture. The study identifies the most applicable forms of publicprivate partnership such as life-cycle contracts. By effectively distributing risks between the customer and the contractor, covering the entire life cycle contracts of a cultural object, combining design, construction and operation into a single complex, they allow to optimize the costs of the creation and operation of cultural objects. The development of publicprivate partnership projects is a real prerequisite for the growth of investment and social attractiveness of the cultural industry and for strengthening the competitiveness of national economies.
\end{abstract}

Keywords-cultural industries; financial support; publicprivate partnerships; life cycle contracts

\section{INTRODUCTION}

The relevance and specificity of the culture, art and creative industry study is due to their huge role in the socioeconomic development of countries in the post-industrial economy in the context of globalization. As a factor in the development of human capital, the culture industry is also an investment sphere, it contributes to the prestigious international positioning of the country, ensures social stability and socio-cultural integrity of the state, it becomes a factor of economic development.

The growing role of culture in society requires increased funding for its development. As the world experience shows, budget funding cannot provide the effective results of this sphere. It is necessary to attract co-financing in this sector from other economic entities, and the main share of investment resources should be private and attracted capital. In these conditions, the development of scientific and methodological approaches to the organization of financial support for the development of cultural industries is in demand today. One of the mechanisms of financing of innovative projects in the sphere of culture industry is the mechanisms of public-private partnership (PPP).

The purpose of this study is to identify the prerequisites for the use of public-private partnership and to determine the effective forms of its organization in the sphere of culture, taking into account the experience of developed countries.

\section{TheORETICAL ANALYSIS: CUlturAL AND CREATIVE INDUSTRIES IN MODERN WORLD}

Technological progress and the growth of the well-being of the population in the world have led to the growth of spiritual demands, interests and opportunities to study intangible cultural values and art. As a result, since the beginning of the $20^{\text {th }}$ century, in modern society a modern structure of the economy has formed, where the service sector occupies a leading place, and a new social and cultural importance of commercial cultural production became the basis of the "era of cultural production" [1].

Services remain a key avenue to realising international trade potential. Trade in services has been more resilient than trade in goods after the global financial crisis in 2008. This trend holds for both developed and developing economies, highlighting the relevance of services for economic development. Trade in services growing $1.3 \%$ in 2015 in developed countries [2].

The rapid development of cultural industries in the 19801990 indicates changes in investment strategies in industrialized countries. There is a global trend towards increased investment in services. Large companies from other sectors of the economy made significant investments in cultural production in the 1990s [3]. As the sector became perceived as a significant economic sector in North America and Europe, cultural industries were seen as a prestigious form of profit-making. 
Cultural industries are a complex business structure, interested in making a profit by producing and distributing works of art and cultural products [4]. The culture and creativity industry is an activity based on individual creativity, skill or talent, which leads to the creation of tangible and intangible values, as well as new jobs through the production and exploitation of intellectual property [5] [6].

The cultural industries are one of the fastest growing sectors in the world, they comprise 13 sectors of cultural and economic activity. About 50-60 \% of the workforce of cultural and creative industries has high qualification and higher education. The cultural and creative industries are recognized as a source of innovation, economic growth, personal well-being and community cohesion.

The structure of the culture and creativity industry includes the following components:

- Advertising (including marketing and public relations);

- Architecture, art and antiques (including auctions);

- Crafts;

- Design and fashion;

- Film and video industry (film production, distribution and display);
- Entertainment interactive programs (video and computer games, educational and reference programs);

- Music (including the publication of musical works, performing arts, publishing;

- Software and computer services (creation, production and supply of software and applications);

- Television and radio broadcasting (state, commercial, cable and satellite television and radio broadcasting, as well as production and broadcasting of programs), etc.

\section{EMPIRICAL ANALYSIS: DYNAMICS OF CULTURAL AND CREATIVE INDUSTRIES}

In developed countries, the cultural and creative industries is considered as one of the important sectors of the economy (as creative economy). According to the World Bank data, the share of this economy is about $7 \%$ of global GDP. According to the UN, the annual growth of the creative economy is at least $8.7 \%$.

Statistics according to UNCTAD in 2016, the growth rate of international trade in cultural services was $3 \%$, a larger increase was observed only in the trade of computer and information services $(4.5 \%)$. The volume of world exports of services reached of $1 / 3$ of the volume of exports of goods. Thus, global trade in services remains unchanged in recent years after a period of sustained growth from 2009 to 2014 as shown in "Table I" [7].

TABLE I. AVERAGE ANNUAL Growth OF EXPORTS AND IMPORTS OF CREATIVE GoOdS, 2003-2015, UNCTAD [7]

\begin{tabular}{|c|c|c|c|c|c|c|}
\hline \multirow{2}{*}{$\begin{array}{c}\text { Years/ Flow } \\
\text { / Product }\end{array}$} & \multicolumn{2}{|c|}{$2003-2015$} & \multicolumn{2}{|c|}{$2007-2011$} & \multicolumn{2}{|c|}{$2012-2015$} \\
\hline & Exports & Imports & Exports & Imports & Exports & Imports \\
\hline All creative goods & 14.62 & 6.27 & 11.66 & 2.03 & -1.92 & -1.47 \\
\hline Art crafts & 7.10 & 3.49 & 5.39 & 1.19 & 0.27 & -0.91 \\
\hline Design & 16.64 & 5.59 & 16.81 & 3.07 & -1.75 & -1.52 \\
\hline Performing arts & 8.68 & 3.69 & 10.18 & 2.23 & -6.97 & -3.75 \\
\hline Publishing & 3.21 & 3.69 & 2.06 & 1.04 & -8.27 & -5.30 \\
\hline Visual arts & 16.23 & 4.35 & & & & \\
\hline
\end{tabular}

In 2016, the contribution of cultural exports to total exports increased in 13 EU countries, most significantly in Poland (+24\%), Latvia $(+11 \%)$ and Croatia $(+10 \%)$. Moreover, in Poland, exports increased 2.5-2.5 times, largely due to an increase in exports of audiovisual and interactive media (films, video games and game consoles) and books. Malta showed the strong decline in cultural exports $(-21 \%)$. Many factors lead to changes in the import or export of cultural goods, they are the economic environment, the digital shift for media, the challenges posed by new technologies. They certainly affect cultural consumption patterns and, consequently, the composition of imports and exports of cultural goods.

Despite the growing value of trade in cultural services between 2011 and 2016, exports of cultural goods outside the EU still account for a relatively low share of total exports outside the EU (1.3\% in 2011 and $1.5 \%$ in 2016). At the national level, only in the UK $(3.7 \%)$, France $(1.8 \%)$ and
Italy $(1.8 \%)$ the share of cultural exports (both within and outside the EU) in 2016 was higher than the EU average (for exports outside the EU). The increasing role of the cultural sphere in society requires increased funding for its support and development [7].

\section{MODELS OF FINANCING OF CULTURE INDUSTRIES}

In world practice, there are three models of financing culture industries:

- European: a significant share of public funding for culture and special mechanisms of tax incentives for financing culture by private individuals;

- American: a small share of public funding for culture and fundraising;

- British: mechanism "private finance initiative", private guarantees of the UK government on the 
obligations of national cultural organizations of special importance.

In most European countries (France, Italy, Germany, Spain, Austria), the state has traditionally provided strong financial support for culture, assuming some influence on the culture. State subsidies for cultural organizations range from 75 to $100 \%$ in developed European countries. But the governments of European countries not only finance culture, but also use economic instruments to stimulate the flow of funds in this area through patronage, sponsorship, fundraising.

For example, in France, legislation from 2003 provides, that investments in culture receive tax benefits in the form of a deduction from income tax up to $60 \%$ of the amount of investments in culture. A contribution in excess of this amount may be deducted from income tax for the next 5 years. The organization-recipient of donations should act for the benefit of society, its activities should be carried out on a non-profit and non-competitive basis, not to generate income to a narrow circle of persons, managed on the principle of disinterest.

In Austria since 1987 sponsorship have been considered as company costs, which removes them from the tax base. In order to be considered costs, sponsorship must be reflected in the media, an active advertising company.

In the Great Britain in 1999 the concept of the "culture and creativity industry" was developed, today it accounts for $5.4 \%$ of the UK economy, and the volume of profits of the culture and creativity industry amounted to $6.2 \%$ of GDP. The involvement of private capital is carried out on the development of the creative industries, providing a comprehensive mix of tourism, visiting historical monuments of culture, museums, various festivals, etc. Only in London there are 20 agencies in the development of creative industries.

With the aim of stimulating private sector participation in the implementation of projects the UK government has developed a number of solutions, in particular, was developed a mechanism of "private finance initiative", involving actions in the framework of contractual procedures, which facilitated the entry of private companies into the public services sector of culture at the expense of a clear definition of the principles of cooperation and framework contracts. Together with professional organization on the business and cultural institutions, it has become an effective tool of integrated communications, strengthened the position of the company in society and contributed to the increase in profits from the cultural sector.

The model of culture financing, which has been implemented in the US, is different from the models of European countries. The share of government spending to support culture in the US is small. This is what contributed to the development of sponsorship and fundraising as a process of attracting money and other resources (human, material, information, etc.), which the organization cannot provide on its own, and which are necessary for the implementation of a certain project in general. In the US, there are conditions in which there are real trends of combining business and culture. In the United States, the state has created the appropriate conditions for this fruitful interaction.

In China since 2002, one of the main measures for the development of the cultural industry has been the policy of gradual removal of restrictions on entering the foreign market, private and foreign investments in the sphere of culture have been encouraged. The state encouraged the participation of non-state capital in about 20 cultural and closely related fields and supported the sale of art, audio and video products, the creation of entertainment projects, and the construction, improvement and management of cultural infrastructure. Various types of private investment, such as sponsorship, joint capital, various forms of cooperation, corporatization of enterprises, franchises were especially developed and encouraged.

The main measures of state support in the world practice for development of the industry of culture and creativity are presented in "Fig. 1". 


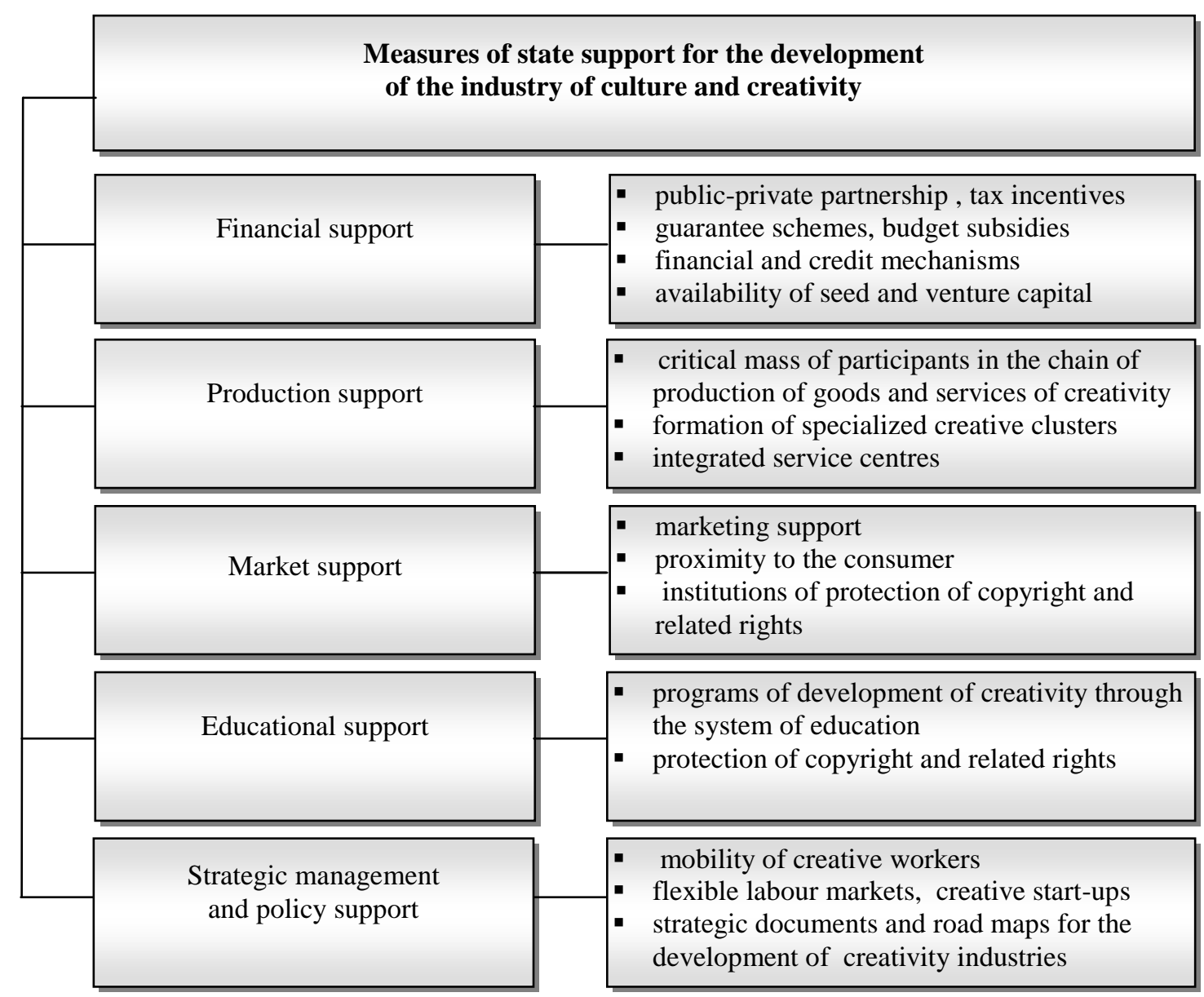

Fig. 1. Measures of state support for the development of the industry of culture and creativity.

\section{RESUltS: PUBliC-PRIVATE PARTNERSHIP AS A} MECHANISM FOR INNOVATION PROJECTS FINANCING IN THE

\section{CULTURE INDUSTRY}

Today, the sphere of culture in all countries requires support not only from the state, but also from society. For the development of the culture industry, it should become attractive for investment. It is necessary to activate new mechanisms for the development of cultural industries, one of which is public-private partnership. In the context of budget constraints, states consider cooperation with business as a way to support and develop the sphere of culture and gradually come to understand the need for the development of the cultural sector on the basis of market mechanisms. Public-private partnership mechanisms are the basic design of attracting non-budgetary investments in the development of various types of infrastructure and non-productive industries. In general, PPP is usually defined as the possibility of involving the private sector in the zone of state responsibility.

The leader of PPP projects among the EU countries in terms of the number of projects and their value is UK - "the birthplace of the idea of PPP". In 201413 EU members implemented at least one PPP project. The sectoral structure of PPP projects in EU countries is shown in "Fig. 2". The largest share of financing in the PPP projects market is in the transport sector. PPP projects in education, health and culture occupy less strong positions. The main reason for the low interest in projects in the field of culture is the priority interest of the state to those projects that have a utilitarian value (water supply, waste management, medicine, transport). 


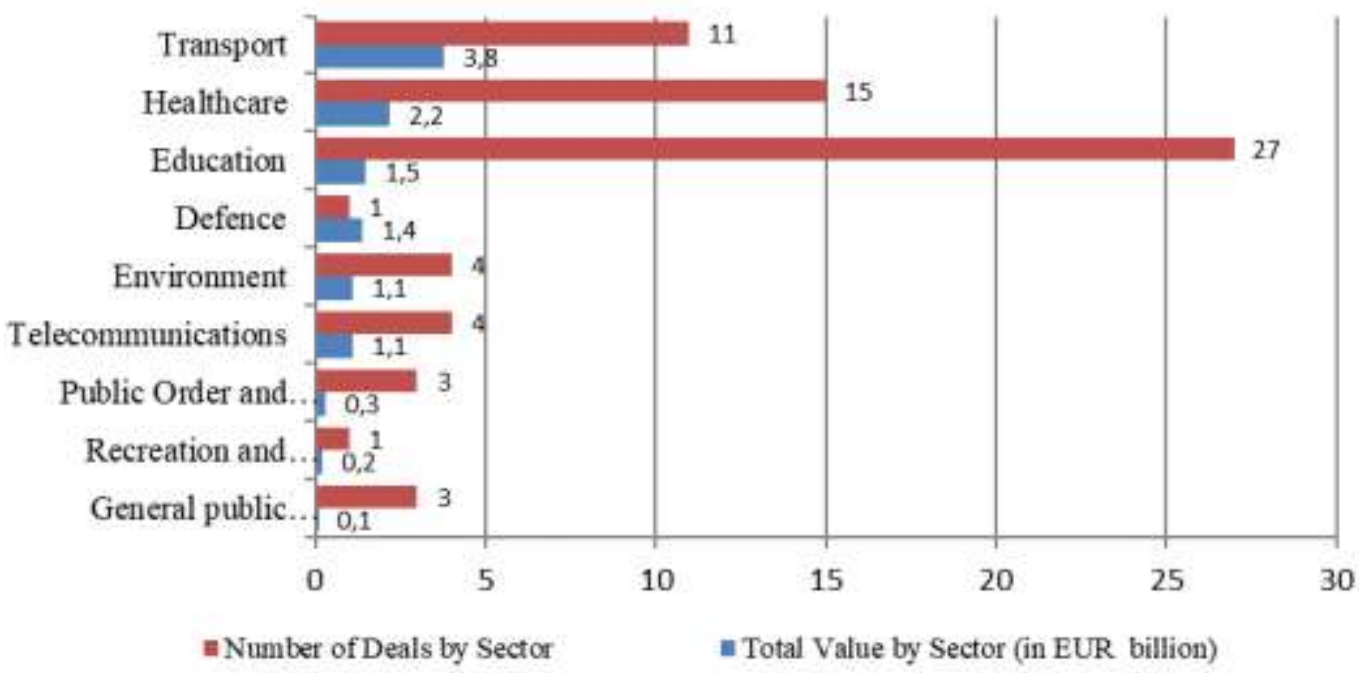

Fig. 2. Sector breakdown by value and number of transactions in 2016. [8]

Public-private partnership as a concept of cooperation between the state and the private sector in socially important areas represents a significant potential for the development of the cultural sphere. Practice in foreign countries has positive experience and there is a general trend of transferring cultural heritage objects to the management of private operators in developed countries.

Along with the preservation of cultural heritage, it is also necessary to develop new innovative projects in the field of culture and art: educational, educational, social, social, museum, historical and leisure projects.

The very use of the principles of financing cultural services on the basis of PPP has the characteristic features of innovation. The presence of scientific and technical novelty, ensuring structural relationship between the various levels of formation, promotion and implementation of cultural services, organization of business processes and crosscutting management of material, financial and related flows with the help of new financial and information technologies contribute to the competitiveness and quality of cultural services and expand the diversity of cultural activities in the context of globalization of the market.

An example of PPP is the adoption of a scheme of private guarantees of the UK government, which determines the procedure for the provision of state guarantees for the obligations of national cultural organizations of special importance (National Gallery, British Museum, British Library, Natural History Museum). The area of application of PPP mechanisms in the cultural sphere in the UK is very extensive: from joint investments in the reconstruction of cultural heritage to the institute of privileged membership in the "clubs of friends of the Museum". In France, if a PPP contract in the cultural sphere is concluded with a museum, then a private partner may be given permission to rent out its halls for a fee for the organization of any prestigious events. In China, more than half of the infrastructure and cultural facilities for the 2008 Beijing Olympic Games were built with using PPP mechanisms.

Public-private partnership in the cultural industries is understood as organizational, legal and financial models fixed in official documents ensuring mutually beneficial interaction of the public and private sectors of economy and culture. The application of such partnership in the cultural industries is considered, first of all, as a mechanism of joint investment of resources in the implementation of social and cultural projects, risk sharing, cost and responsibility in the course of implementation of such projects on a contract basis. State participation in socio-cultural projects is caused by the need to stimulate innovative cultural processes that the market environment cannot cope with.

Despite the diversity of specific forms, the fundamental principle of public-private partnership in the cultural sphere remains unchanged. The public assets are transferred on a temporary basis to the disposal of private business, which benefits from the provision of public services, but assumes the investment risk associated with this activity. At the same time, the state retains control over the volume and quality of services provided on the basis of public-private partnership. The principles of such control are defined in a contract between a private company and a public authority.

\section{DISCUSSION: FORMS OF PPP IN CULTURE}

Discussing the applicability of different forms of projects organization in the field of cultural industries using the mechanisms of public-private partnerships, we can note that the most applicable in this area the lifecycle of Life Cycle Contracts (LCC). This is a type of concession type Design Build - Finance - Maintain (DBFM), this form is based on the "Private finance initiative" model used in the UK and many countries.

For example, one of the most well-known projects of the LCC is the construction of a high-speed railway tunnel under the English Channel. In this project, the private partner carried out the design, construction, financing, operation and maintenance. The LCC mechanism can be effective in 
relation to new cultural objects, galleries and museums, innovative projects launched.

LCC is defined as a contract form of PPP, when a public partner enters into a competitive agreement with a private partner for the design, construction and operation for the life cycle of the facility and pays for the project after the facility is commissioned, provided that the private partner maintains the facility in accordance with the specified functional requirements.

A private investor builds or reconstructs an object and makes it available for public use, that is, provides cultural services with its help in accordance with the agreements, and a public institution (state or municipality) pays for the services to provide it for use.

In the implementation of the LCC, the private partner is responsible for the entire life cycle of the project: designs, builds, operates, and finances the creation of a cultural facility.

During the implementation of the project on the basis of LCC, the state receives services of the cultural sphere, and the private partner (provider) receives payments for these services (availability payment), which include payments for the service of the debt, and the funds necessary to ensure the return and profitability of investments.

Financial resources to the project are attracted by a private partner on the terms of project financing through a special project company. The public partner is not an investor in the PPP agreement, but only pays for the goods, works and services created after its entry into force.

By distributing risks effectively between the customer and the contractor, covering the entire life cycle of the cultural object (up to 40 years and more), combining the design, build, finance and maintain into a single complex, the life cycle contracts allow for significant optimization of the costs for the creation and operation of the cultural object.

\section{CONCLUSION}

In conclusion, we note that the structure of funding sources for cultural industry projects in the world reveals the imbalance between the public and private sectors and the asymmetry between the needs of the economy and the possibilities of financing these projects. The demand to compensate for these imbalances determines the main tasks of public-private partnership in the field of culture:

- The effective distribution of limited resources in the field of culture:

- The formation of new segments of the cultural services market;

- Infrastructure development;

- Taking into account the specific needs of different regions of the world;

- Reducing the risks of private investors;
- Support for social and cultural projects at the stage of development and implementation

- Assistance to small and medium-sized forms of cultural entrepreneurship;

- The integration of cultural organizations, society and business.

Development of PPP projects is a real prerequisite for the growth of investment and social attractiveness of the cultural industry and strengthening the competitiveness of national economies.

Therefore, public-private partnerships are an integral part of the modern economy, which allow to improve the quality of public goods provided by the state without resorting to an increase in the taxes. The concession agreements of PPP in the form of Life Cycle Contracts allow to make capital investments in the fixed assets of cultural institutions, which have a deficit of budgetary funds and at the same time have commercial attractiveness for investors. The directions of development of public-private partnership are currently quite multifaceted: state and political support, organizational, economic, investment and financial conditions, regulatory framework, staffing. Using the mechanism of public-private partnership in the cultural industry, an innovative business environment is formed, which helps to attract additional resources and potentials of the state and business.

\section{REFERENCES}

[1] T. Kartushina, A. Firsova, The commercialization of optical techniques in Russian regions: experience and problems, Proc. SPIE 5771, 2004: Optical Technologies in Biophysics and Medicine VI, http: doi:10.1117/12.634865.

[2] World economic situation and prospects 2017. United Nations Statistics Division, URL: https://www.un.org/development/desa/dpad/wpcontent/uploads/sites/45/2017wesp_chap2_en.pdf

[3] P. Bourbieu, The field of cultural production: essays on art and literature/ R. Jonson. Cambridge: Polity press, 1993, p. 21.

[4] D. Hezmondalsh, Cultural industry, Moscow: Publishing House of Higher School of Economics, 2014, p. 81.

[5] S. Roodhouse, The creative industries: definitions, quantification and practice. URL: http://edoc.huberlin.de/conferences/culturalindustries/roodhousesimon/PDF/roodhouse.pdf

[6] N. Garnham, From cultural to creative industries. An analysis of the implications of the "creative industries" approach to arts and media policy making in the United Kingdom, International Journal of Cultural Policy, 2005, vol. 11, no. 1, pp. 15-29.

[7] UNCTADSTAT, URL: http://unctadstat.unctad.org/wds/TableViewer/tableView.aspx

[8] Market update review of the European PPP market in 2016, URL: http://www.eib.org/attachments/epec/epec_market_update_2016_en.p $\mathrm{df}$ 